\section{Report urges US to spend more money on $\mathrm{R}$, but not $\mathrm{D}$}

[WASHINGTON] The US government should support more basic research at universities, rationalize its own laboratories, and avoid supporting technology development, according to a study by business leaders and academics.

The study, 'America's Basic Research', was conducted by the Committee for Economic Development (CED), an industry-backed think-tank. It argues that government support for basic research is critically important to US industry, but that technology development ought to be paid for by industrial corporations.

The report applauds the performance of the research universities but singles out the laboratories of the Department of Energy for criticism. They "have not acted forcefully to eliminate work in areas no longer relevant to their missions, nor to expose themselves to merit-based peer-review processes," the report claims.

But William Beeman, director of economic studies at CED, admits that the report's authors did not consult the energy department about these criticisms. Department officials argue that considerable progress has been made since similar criticisms were voiced in a celebrated 1995 report from a panel chaired by Robert Galvin, former chairman of the Motorola electronics corporation. "We were essentially endorsing the views of others who have looked at the laboratories," Beeman admits.

He adds that the study's main finding is that government support for science, and not technology, matters to the panel members. The panel started by looking broadly at science and technology, he says, but ended up concentrating on basic research because that was what mattered to the industrialists on the panel.

"They are not concerned about support for technology development," Beeman says. "They reject the argument that it is needed to ensure international competitiveness - and most academics reject that too."

These conclusions were immediately contested by Senator Jay Rockefeller (Democrat, West Virginia), an advocate of technology programmes, whom CED asked to speak at its report's launch. "I remain convinced that these programmes fill a very clear void that industry would not fill on its own," he said.

The CED report condemns the widespread congressional practice of 'earmarking' research money for projects at specified locations. It also calls for guidelines to ensure that relationships with industry do not damage the "primary basic research mission" of universities.

\title{
Framework programme to get new advisory system
}

[MUNICH] The European Commission in Brussels is revamping the structure of its research advisory system in order to improve the management of its Fifth five-year Framework Research programme (FP5), which is due to begin next year.

The new structure includes the setting up of external advisory groups to oversee each of the 17 or so 'key actions' — the detailed research areas into which FP5 is divided. A call for nominations for membership of these groups should be published by the commission this week.

There will also be a 'two-chamber' body, one representing industry and the other the academic community, to advise on European Union research policy in general.

The commission sees this as a restructuring of its two existing advisory bodies, the European Science and Technology Assembly (ESTA), a 61-strong group of scientists and industrialists set up in 1994 to advise on the commission's research policy, and the 25member Industrial R\&D Advisory Committee (IRDAC), set up in 1984.

The commission says that a new system is necessary because, unlike the current framework programme of research, FP5 is closely focused on key actions and socio-economic objectives. According to a commission spokesman, the close relationship in FP5 between the discoverers of knowledge - primarily researchers - and those exploiting that knowledge - primarily industry and consumers - needs to be reflected in its advisory structure.

The research ministers of EU member states, who met informally in April to discuss the commission's research management practices (see Nature 392, 849; 1998), are keen that the advisory groups should be in place by the summer to provide input into the key actions' working programmes before 'calls for proposals' are put out at the end of the year.

Most of the key actions will have their own external advisory group made up of 15 to 20 members from the industrial and research communities, as well as relevant stakeholders. However, the four key actions associated with FP5's information technology programme will share one advisory group because of their integrated nature.

The groups will follow progress within their key actions to ensure that objectives are being met. They will advise on appropriate criteria for evaluating the actions, and, when felt necessary, on how their aims should be re-orientated.

The chairmen of each group will be members of one of the two proposed chambers.
Other members will be nominated by the commission, which says there will be "a balanced representation of the various research disciplines and economic sectors as well as an appropriate geographical and gender distribution".

The commission wants the chambers in place by the end of the year. They would share a secretariat in Brussels, and would be expected to work jointly or separately on topics that would be either set by the commission or proposed by the chambers themselves. Details of how it would work in practice are yet to be worked out.

The new system is said to have the support of the EU research ministers, although their formal approval is not required. There is also support from IRDAC, which last year suggested that the commission should combine its advisory forces given FP5's highly target-orientated structure.

But within ESTA, which is generally thought to have less influence than IRDAC on EU research policy, feelings are mixed.

Alexandre Quintanilha, a member of ESTA's 11-strong bureau, which discussed the issue with commission officials last week, says the bureau responded to the proposed two-chamber system with "guarded optimism".

Quintanilha, who is director of the Institute for Molecular and Cellular Biology in Oporto, Portugal, says the system could work well on topics such as technology transfer. But he says that ESTA members are worried that the views of the academic community may be overwhelmed by those of industry.

Frank Gannon, however, director of the European Molecular Biology Organization, welcomes the proposed changes, arguing that ESTA was always in danger of being marginalized because of FP5's strong orientation towards product development.

Jan Borgmann, ESTA's first chairman, says he is "surprised that the changes to the commission's advisory structures are happening so quickly and are so radical", given that ESTA has only been established for four years, and its new assembly has only been in place for six months. He is also concerned that the commission's desire to secure a geographical balance in the two chambers may weaken their influence.

ESTA's current assembly was appointed for a two-year period last autumn, and has since been deliberating on how to interact with the commission over issues relating to FP5. Other activities under consideration have been suspended until decisions are made about its future.

Alison Abbott 